Przegląd Prawa Konstytucyjnego

----ISSN 2082-1212-----

DOI 10.15804/ppk.2019.03.04

-----Nr $3(49) / 2019-----$

\title{
Diana Pustuła ${ }^{1}$
}

\section{Znaczenie doktryny stare decisis dla sądowej kontroli konstytucyjności prawa USA - między stabilnością orzecznictwa a instrumentalizmem}

Słowa kluczowe: stare decisis, sądownictwo konstytucyjne, kontrola sądowa, precedens, aktywizm sędziowski, Sąd Najwyższy, Konstytucja Stanów Zjednoczonych

Keywords: stare decisis, constitutional judiciary, judicial review, precedent, judicial activism, Supreme Court, US Constitution

\section{Streszczenie}

Uprawnienie do badania zgodności aktów prawnych z konstytucją, stanowiących podstawę wydania rozstrzygnięcia, przysługuje wszystkim sądom amerykańskim, tworząc rozproszony system kontroli konstytucyjności. Czynnikiem stabilizującym orzecznictwo stają się precedensy sądowe oraz doktryna stare decisis. Jednakże niełatwo dokonać jednoznacznej oceny roli doktryny stare decisis dla sądowej kontroli konstytucyjności prawa USA (judicial review) z uwagi na szereg czynników, które wpływają na jej znaczenie. Można do nich zaliczyć formalny brak bezwzględnego charakteru rozstrzygnięć sądowych, czy też brak związania Federalnego Sądu Najwyższego USA własnymi orzeczeniami. Ten ostatni wydaje się szczególnie istotny w przedmiotowej ocenie w kontekście znacznego aktywizmu sędziowskiego oraz sposobu nominowania i zatwierdzania sędziów na, co do zasady, dożywotnich stanowiskach. W niniejszej publikacji analizie poddane zostały wszystkie wyżej wymienione czynniki w celu dokonania możliwie rzetelnej oceny znaczenia doktryny stare decisis dla sądowej kontroli konstytucyjności prawa USA.

ORCID ID: 0000-0001-6627-4520, magister, Wydział Prawa i Administracji, Uniwersytet Jagielloński. E-mail: diana.pustula@doctoral.uj.edu.pl. 


\begin{abstract}
The importance of the stare decisis doctrine for judicial control of the constitutionality of US law - between the stability of jurisprudence and instrumentalism
\end{abstract}

\begin{abstract}
All American courts have a right to examine the conformity of legal acts with the Constitution as the basis for issuing a decision, creating a diffused system of judicial review. Court precedents and the stare decisis doctrine become the stabilizing factor of jurisprudence. However, it is not easy to make an unequivocal assessment of the role of the stare decisis doctrine for judicial review due to a number of factors that affect its significance. They include the formal lack of absolute nature of the court decisions, or the fact that the Federal US Supreme Court is not bound by its own rulings. The latter fact seems particularly important in the assessment of the subject matter in the context of considerable judicial activism and the way the judges are nominated and approved for, in principle, lifetime positions. In this publication, all the above-mentioned factors have been analyzed in order to assess the significance of the stare decisis doctrine for judicial review in the US as accurately as possible.
\end{abstract}

$*$

Obowiązująca w systemie common law zasada Stare decisis et not quieta movere oznacza: „pozostań przy podjętej decyzji”. W myśl tej zasady decyzje sądów wyższych instancji są wiążące dla sądów niższych instancji we wszystkich podobnych sprawach, a sąd nie powinien zmieniać własnych decyzji bez ważnej przyczyny.

Doktryna ta znana była we wszystkich systemach sądowniczych, a jej pełen rozwój dokonał się w angielskim systemie common law i opiera się na zasadzie stanowiącej, że stabilność i pewność prawa są najważniejsze. Ma ona ogromne znaczenie dla całego anglo-amerykańskiego systemu sądownictwa ${ }^{2}$, choć mocniej oddziałuje w prawie prywatnym niż publicznym ${ }^{3}$.

2 Zob. R.H. Fallon, Jr., Stare Decisis and the Constitution: An Essay on Constitutional Methodology, "New York University Law Review”, maj 2001, t. 76, nr 2, s. 596. Autor zwraca uwagę, że doktryna stare decisis, w świetle jej wieloletniej akceptacji oraz względów sprawiedliwości i rozwagi, zasługuje na uznanie jako uzasadniona, upoważniona z mocy Konstytucji, wykraczająca poza prawo Kongresu do sprawowania kontroli.

3 Zob. C.W. Collins, The Fourteenth Amendment and the States, Boston 1974, s. 110-111. 
Trudno jednoznacznie ocenić rolę doktryny stare decisis dla sądowej kontroli konstytucyjności prawa USA (judicial review) szczególnie w kontekście znacznego aktywizmu sędziowskiego, braku bezwzględnego charakteru rozstrzygnięć sądowych, braku związania Federalnego Sądu Najwyższego USA (SN) własnymi orzeczeniami oraz sposobu nominowania i zatwierdzania sędziów na, co do zasady, dożywotnich stanowiskach. W zbiorach orzecznictwa SN znajdują się zarówno wyroki, które wskazują na mocne przywiązanie niektórych składów sędziowskich lub poszczególnych sędziów do jej stosowania, jak również takie, które uzasadniają odejście od jej bezwzględnego przestrzegania, a nawet takie, które ją wyraźnie ignorują, opowiadając się za dyskrecjonalnym podejściem Sądu do wydawania orzeczeń i ustanawiania nowych precedensów, nawołując jednocześnie do przestrzegania tych ostatnich, o ile np. nie byłoby to oczywistym błędem ${ }^{4}$. Podobnie podzielone opinie panują wśród przedstawicieli doktryny. Jedne i drugie poglądy zostały przedstawione w tym artykule.

Uprawnienie do badania zgodności aktów prawnych z konstytucją, stanowiących podstawę wydania rozstrzygnięcia, przysługuje wszystkim sądom amerykańskim bez względu na umiejscowienie w systemie sądownictwa (stanowe, federalne), czy też w strukturze (sądy dystryktowe, apelacyjne, sądy najwyższe (Stanowe Sądy Najwyższe, Federalny SN) ${ }^{5}$, tworząc rozproszony system kontroli konstytucyjności w USA ${ }^{6}$.

Brak scentralizowanego sytemu kontroli sprzyja, w oczywisty sposób, rozchwianiu linii orzeczniczych, a przez to brakowi przewidywalności prawa i spójności procesu sądowego, wpływając na poczucie braku pewności prawa przez obywateli. W konsekwencji, w systemie common law szczególną rolę „stabilizującą" orzecznictwo odgrywają precedensy tworzone przez sądy oraz doktryna stare decisis ${ }^{7}$. W przypadku sądu apelacyjnego jego wyrok jest wiążący dla sądów mu podległych i dla niego samego. Rygoryzmowi związania własnymi

4 Jednym z najciekawszych pod tym względem orzeczeń jest wyrok w sprawie Citizens United v. Federal Election Comm'n, 558 U.S. 310 (2010).

A.R. Brewer-Carías, Judicial review in comparative law, Cambridge 1989, s. 138.

6 Por. P. Mikuli, Zdekoncentrowana sądowa kontrola konstytucyjności prawa. Stany Zjednoczone i państwa europejskie, Kraków 2007, s. 52.

Por. R.H. Fallon, op.cit., s. 585; R.J. Kozel, Stare Decisis as Judicial Doctrine, „Washington and Lee Law Review”2010, t. 67. 
orzeczeniami nie podlega natomiast $\mathrm{SN}$, który stojąc na czele sądownictwa, rozpatruje odwołania „od orzeczeń apelacyjnych sądów federalnych oraz od orzeczeń sądów stanowych najwyższej instancji”". Jednakże, co do zasady, SN może przejąć każdą sprawę oraz ma dyskrecjonalne prawo dobierania sobie spraw wg uznania w zależności od doniosłości problemów konstytucyjnych i rozpatrywania ich na podstawie wydawanej przezeń zgody - writ of certoriari ${ }^{9}$.

Choć już w latach dziewięćdziesiątych XVIII w. SN bada zgodność z konstytucją ustaw stanowych i federalnych ${ }^{10}$, to próżno szukać takiego uprawnienia sądów wprost w konstytucji, ponieważ „nie wynika [ono - przyp. autora] bezpośrednio $z$ amerykańskiej ustawy zasadniczej, lecz ukształtowało się jako rezultat orzecznictwa”"1. „Uzasadnienie dla uprawnień kontrolnych sądów w Stanach Zjednoczonych wydaje się wynikać także z ugruntowanej tradycji common law, tj. uznania że sądy są w dużej mierze twórcami norm oraz przywiązania do konstytucji, będącej gwarantem wolności. Trzeba też pamiętać o wyjątkowej sztywności amerykańskiej ustawy zasadniczej, stąd potrzeba jej sądowej kontroli i wykładni"12. W przypadku ustaw federalnych uprawnienie to zostało wywiedzione $\mathrm{z}$ całego systemu konstytucyjnego w drodze orzeczenia przez SN, który w sprawie Marbury v. Madison (1803 r. $)^{13}$ po raz pierwszy stwierdził niekonstytucyjność przepisów ustawy wydanej przez Kongres, częściowo ją unieważniając. SN argumentował, że skoro najwyższym aktem prawnym w państwie jest Konstytucja Stanów Zjednoczonych, to wszystkie akty niższego rzędu muszą być z nią zgodne ${ }^{14}$, a w konsekwencji Kongres nie może uchwalać ustaw z nią sprzecznych oraz, że rolą systemu sądowniczego jest interpretowanie przepisów prawa, a także niestosowanie prawa sprzecznego z konstytucją ${ }^{15}$. „Kompetencję [SN - przyp. autora] do kontroli konstytucyjności ustaw stanowych wyprowadzano ${ }^{16} \mathrm{z}$ art. IV ust. 2 Konstytucji, któ-

\footnotetext{
$8 \quad$ P. Mikuli, op.cit., s. 48.

9 L. Garlicki, Sąd Najwyższy Stanów Zjednoczonych Ameryk: konstytucja-polityka - prawa obywatelskie, Wrocław 1982, s. 52.

10 Zob. P. Mikuli, op.cit., s. 21-22.

11 Ibidem, s. 19.

12 Ibidem, s. 104.

13 Marbury v. Madison, 5 U.S. 1 (1803).

14 P. Mikuli, op.cit., s. 21-22.

15 A.R. Brewer-Carías, op.cit., s. 136-137.

16 Np. w sprawie Hollingsworth v. Virginia, 3 U.S. 378 (1798).
} 
ry mówi o wyższości prawa federalnego nad stanowym"17 (supremacy clause). Skoro żadne prawo nie może być niezgodne z konstytucją, „kompetencje sądów nie ograniczają się więc jedynie do badania zgodności ustaw z konstytucją, ale mają charakter uniwersalny, obejmując kontrolę wszelkich form działania aparatu państwowego"18, a to oznacza rozległe kompetencje kontrolne sądów USA, szczególnie zaś SN, z uwagi na jego rangę w systemie sądownictwa amerykańskiego.

Za ciekawy zbieg okoliczności można uznać fakt, że pierwszym przepisem ustawy federalnej uznanym za niezgodny z konstytucją była paradoksalnie klauzula dotycząca uprawnień samego SN, które zostały rozszerzone o wydawanie tzw. writs of mandamus ${ }^{19}$ (na podstawie $\$ 13$ ustawy o sądownictwie z 1789 r. (Judiciary Act of $1789^{20}$ ), wykraczając poza zakres pierwotnej jurysdykcji SN określony w Konstytucji.

Zważywszy na to, iż sądy w amerykańskie badają zastosowanie normy w konkretnej sprawie (as apply), nie badają spraw o charakterze abstrakcyjnym. Rozstrzygniecie (formalnie) ma zatem charakter względny - tylko inter partes. Zakwestionowana norma zyskuje status null and void nie znajdując zastosowania, ale tylko w danej sprawie. Nawet jeśli SN uzna cały tekst ustawy za niekonstytucyjny i pozbawiony skutków prawnych (facial), to taki akt prawny nie zosta-

17 P. Mikuli, op.cit.

18 L. Garlicki, op.cit., s. 97.

19 "Judiciary Act of 1789, SEC. 13. (...) The Supreme Court shall also have power to issue (...) writs of mandamus, in cases warranted by the principles and usages of law, to any courts appointed, or persons holding office, under the authority of the United States, Federal Judicial Centre", https://www.fjc.gov/history/legislation/landmark-judicial-legislation-back-historical-note-0 (03.06.2018).

20 Konstytucja Stanów Zjednoczonych w art. III \$1 stanowi, iż: „Władzę sądową Stanów Zjednoczonych sprawuje jeden Sąd Najwyższy oraz takie sądy niższe, jakie z biegiem czasu Kongres ustanowi i utworzy" nie określiła tych sądów, a tym bardziej ich składu, czy procedur któregokolwiek z nich, pozostawiając te kwestie do rozstrzygnięcia Kongresowi. Tę prerogatywę Kongresu odnajdziemy również w art. I $\$ 8$ Konstytucji - „Kongres ma prawo tworzyć sądy niższe w stosunku do Sądu Najwyższego". Ten zaś za sprawą Judiciary Act z 1789 r. powołał do życia sądownictwo federalne z SN na czele. Przekład tekstu Konstytucji Stanów Zjednoczonych: http://libr.sejm.gov.pl/tek01/txt/konst/usa.html (03.06.2018) na bazie tekstu zamieszczonego w wydawnictwie Służb Badawczych Kongresu pt.: The Constitution of the United States of America. Analysis and interpretation, US Government Printing Office, Washington 1987, s. 1-44. 
je uchylony, ale nadal pozostaje w zbiorach prawa, ponieważ SN może z czasem zmienić własną interpretację danego przepisu, czy całej ustawy i przywrócić ich stosowanie poprzez usuwanie własnych orzeczeń ${ }^{21}$ (overruling).

Jak zatem pogodzić względny charakter rozstrzygnięć z doktryną stare decisis, a tę z overruling? Rozstrzygnięcia sądowe mają charakter względny jedynie w wymiarze teoretycznym właśnie z uwagi na doktrynę stare decisis i związanie sądów precedensami przy rozpatrywaniu spraw podobnych (fakty materialne i niematerialne). Oddziaływanie wydawanych przez sądy orzeczeń powiązane jest pewnością z instancją stąd orzeczenia SN wiążące dla wszystkich sądów niższych instancji w sensie praktycznym wpływa na ujednolicenie interpretacji Konstytucji i zapobiega wydawaniu wzajemnie sprzecznych orzeczeń, a tym samym wywołuje skutki takie jak orzeczenie Trybunału.

SN zawsze orzeka w pełnym składzie. Od 1869 r. zasiada w nim 9 osób. W przypadku decyzji większościowych sędziowie, którzy podzielają podjętą decyzję, ale nie zgadzają się z przedstawionym wywodem, wyrażają zbieżne opinie (concurring opinions), a ci którzy się z nią nie zgadzają wyrażają swą krytykę względem decyzji i jej uzasadnienia w zdaniach odrębnych (dissenting opinions) ${ }^{22}$. Z takich właśnie opinii dowiadujemy się również często o podejściu SN, czy też poszczególnych sędziów, do stosowania zasady stare decisis przy wydawaniu kolejnych orzeczeń w podobnych sprawach, zgodnie z którą sąd powinien trwać przy podjętej decyzji i nie zmieniać jej bez ważnej przyczyny. Analiza orzecznictwa SN wskazuje jednak na to, iż zasada ta w odniesieniu do kontroli konstytucyjności prawa nie tylko nie zawsze jest ściśle przestrzegana ${ }^{23}$, ale wręcz trak-

21 A.R. Brewer-Carías, op.cit., s. 149, L. Garlicki, op.cit., s. 98.

22 A.M. Ludwikowska, R.R. Ludwikowski, Sądy w Stanach Zjednoczonych. Struktura i Jurysdykcja, Toruń 2008, s. 29.

23 SN w orzeczeniu w sprawie Arizona v. Rumsey, 467 U.S. 203 (1984) przyznaje, że doktryna stare decisis nie jest sztywno stosowana w kwestiach konstytucyjnych. Zaznacza jednak, że każde odejście od niej wymaga specjalnego uzasadnienia; W orzeczeniu w sprawie Payne v. Tennessee, 501 U.S. 808 (1991) uchylającym wcześniejsze precedensy w sprawach Booth v. Maryland, 482 U.S. 496 (1987) oraz South Carolina v. Gathers 490 U.S. 805 (1989), SN stwierdza, że chociaż przestrzeganie doktryny stare decisis jest zazwyczaj najlepszą polityką, doktryna nie jest bezwzględnym nakazem. Trybunał nigdy nie czuł się związany precedensem, gdy obowiązujące decyzje są niewykonalne (unworkable) lub źle uzasadnione (badly reasoned), 
towana instrumentalnie ${ }^{24}$. Dobrym przykładem na to, jak dalece sędziowie SN mogą różnić się między sobą w podejściu do tej zasady, jest orzeczenie Smith v. Allwright (1944) ${ }^{25}$, w którym to uzasadnienie większościowego wyroku, wydanego stosunkiem głosów 7:2, przedstawionego przez sędziego Reeda, zawiera stwierdzenie, że uchylając poprzedni precedens - Grovey v. Townsend $(1935)^{26}$, na podstawie ugruntowanej zasady XV Poprawki, zabraniającej ograniczania przez państwo prawa obywatela do głosowania, SN jest świadomy celowości ciągłości decyzji w kwestiach konstytucyjnych, jednakże będąc przekonanym o błędności poprzednich decyzji (erroneous decissions), nigdy nie czuł się zmuszony do przestrzegania precedensu, wykonując swoje uprawnienia do ponownego zbadania podstaw swoich decyzji konstytucyjnych. SN podkreślił, że jest to praktyka od dawna akceptowana i kontynuowana. W tym samym orzeczeniu sędzia Roberts w zdaniu odrębnym ponawia krytykę wobec polityki Sądu w zakresie stosowania zasady „stare decisis”. Stwierdza on, iż Sąd ze swobodą lekceważy i uchyla poprzednie decyzje, a przez to i zasady prawa, które głoszą. Ta tendencja, wg sędziego Robertsa, wskazuje na nieakceptowanie tego, co sędziowie SN w przeszłości świadomie i celowo postanowili oraz zakłada, że wiedza i mądrość przynależy jedynie temu Sądowi, w przeciwieństwie do jego po-

szczególnie w sprawach konstytucyjnych, gdzie korekta poprzez działania legislacyjne jest praktycznie niemożliwa, oraz w sprawach dotyczących zasad proceduralnych i dowodowych. ${ }^{24}$ Co więcej, większość krytyków uważa, że doktryna stare decisis stosowana jest arbitralnie przy wydawaniu orzeczeń w zakresie prawa konstytucyjnego. Na potwierdzenie tego faktu przywołuje się orzeczenia takie jak, np. dotyczące kwestii federalizmu amerykańskiego w kontekście płacy minimalnej i nadgodzin: Garcia v. San Antonio Transit Auth., 469 U.S. 528 (1985), którego wydanie spowodowało uchylenie wcześniejszego orzeczenia w sprawie National League of Cities v. Usery, 426 U.S. 833 (1976), gdzie to ostatnie doprowadziło do uchylenia poprzedzającego je orzeczenia w sprawie Maryland v. Wirtz, 392 U.S. 183 (1968) - zob. w Constitutional Stare Decisis, „Harvard Law Review” 1990, t. 103, nr 6, s. 1345. W zdaniu odrębnym do orzeczenia Garcia v. San Antonio Transit Auth. (1985) sędzia Powell stwierdza, że istnieją oczywiście liczne przykłady z historii SN uchylenia swoich wcześniejszych decyzji. Jednakże, jedynie w kilku przypadkach zasada stare decisis i przesłanki wydania ostatnich decyzji były ignorowane tak gwałtownie, jak w przypadku zapadłego właśnie orzeczenia, uchylającego poprzednie.

${ }_{25}$ Smith v. Allwright, 321 U.S. 649 (1944).

26 Orzeczenie w sprawie Grovey v. Townsend, 295 U.S. 45 (1935) dotyczące zakazu głosowania w prawyborach czarnoskórym obywatelom, ustanowionego w konwencji stanowej Demokratycznej Partii Teksasu - na co zezwalało prawo stanowe. 
przedników. Porównuje wyrok SN odrzucający precedens sprzed 9 lat do biletu kolejowego, który jest ważny jedynie w danym dniu i na tylko na przejazd konkretnym pociągiem. Wyraża również obawę, że właśnie wydane orzeczenie zostanie wkrótce podważone i uchylone przez sędziów, którzy uważają, że rozpatrują sprawę w nowym świetle.

Zaniechanie konsekwentnego stosowania zasady stare decisis pozwala SN na uelastycznienie interpretacji przepisów Konstytucji, a także wycofanie się z orzeczeń uznanych za błędne, czy wręcz wstydliwe, np. orzeczenia SN dot. segregacji rasowej ${ }^{27}$, oraz na dostosowywanie orzeczeń do panującej sytuacji społeczno-politycznej ${ }^{28}$. Jednakże dostosowanie decyzji do panujących okoliczności może oznaczać zarówno uwzględnianie oczekiwań społeczeństwa, jak i polityków nominujących sędziów SN (prezydent ${ }^{29}$ ) lub zatwierdzających ich kandydatury (Kongres).

27 Orzeczenie SN w sprawie Plessy v. Ferguson, 163 U.S. 537 (1896), dotyczącej wprowadzenia odrębnych wagonów o jednakowym standardzie dla ludności białej i czarnej, sankcjonujące segregację rasową poprzez wprowadzenie doktryny separate but equal. Długi brak zmiany na stanowiskach sędziowskich „zacementował” ten precedens na dekady (58 lat) przełamany dopiero orzeczeniem SN w sprawie Brown v. Board of Education of Topeka, 347 U.S. 483 (1954), dotyczącej segregacji rasowej w szkołach o podobnym standardzie, które znosi zasadę separate but equal, a tym samym segregację rasową, którą SN uznaje za niedopuszczalną z uwagi na fakt, iż zgodnie z Konstytucją wszyscy są równi wobec prawa; Orzeczenie w sprawie Smith v. Allwright, 321 U.S. 649 (1944). SN stwierdził naruszenie XIV poprawki do Konstytucji i uchylił po 9 latach wyrok w sprawie Grovey v. Townsend, 295 U.S. 45 (1935), przyczyniając się do zniesienia segregacji rasowej w sferze polityki.

28 Zob. S.J. Burton, The Conflict between Stare Decisis and Overruling in Constitutional Adjudication, "Cardozo Law Review” 2014, t. 35. s. 1688, 1713; Autor zauważa, że zarówno zasada stare decisis jak i overruling są ważne w systemie prawa. Nie ma między nimi konfliktu. Zasada przyczynia się do zachowania jednolitości, stabilności i równości w czasie. Możliwość uchylenia wyroku zaś do naprawienia błędów z przeszłości i dostosowania prawa do zmieniających się okoliczności; D.A. Farber, The Rule of Law and the Law od Precedents, „Minnesota Law Review” 2000, t. 90, s. 1202-1203 - autor zwraca uwagę, że należy odróżnić stabilność od sztywności. Maksymalizacja tej pierwszej może wymagać elastyczności wystarczającej do dostosowania się do zmieniających się wizji konstytucyjnych.

29 Np. nominowanie przez prezydenta Ronalda Regana sędziów SN o konserwatywnych poglądach dotyczących Konstytucji, gotowych poddać rewizji liberalne doktryny konstytucyjne, w tym dotyczące ograniczenia prawa do aborcji (Webster v. Reproductive Health Svcs., 492 U.S. 490 (1989)); Zasięg „dziedzictwa” Regana zależeć będzie po części od poszanowania Sądu dla doktryny stare decisis - zob. w Constitutional Stare Decisis..., s. 1344; J.A. Maltese, The selling of Supreme Court nominees, Baltimore; London 1995, s. 123. 
Nie bez wpływu na wydawane decyzje zmieniające albo utrzymujące wcześniejsze interpretacje mogą pozostawać poglądy poszczególnych sędziów (przesłanki ideologiczne) przede wszystkim w odniesieniu do spraw dotyczących tak ważkich kwestii jak prawa i wolności obywatelskie, ale nie tylko. Przykładami takich orzeczeń mogą być liberalne orzeczenia SN dotyczące naruszenia wolności wyznania ${ }^{30}$, prawa do aborcji ${ }^{31}$, a także orzeczenia konserwatywne dotyczące posiadania broni ${ }^{32}$, czy finansowania kampanii wyborczych ${ }^{33}$.

Czynniki takie jak: swobodny dobór spraw, które może rozpatrywać SN, sposób obsadzania stanowisk sędziowskich, na które zgodnie z art. II $\$ 2$ Konstytucji, Prezydent wyznacza, a za radą i zgodą Senatu mianuje (...) sędziów SN $(. . .)^{34} \mathrm{w}$ sytuacji, gdy ustawa nie określa wymogów, jakie musi spełniać kandydat na sędziego $\mathrm{SN}^{35}$, dożywotnie, co do zasady, sprawowanie stanowisk

30 Orzeczenie SN w sprawie McCollum v. Board of Education, 333 U.S. 203 (1948), dotyczące szkół publicznych zezwalających grupom religijnym na wykorzystywanie swoich obiektów do nauczania dzieci religii, uznające zezwalanie na tego rodzaju praktyki w szkołach publicznych za niekonstytucyjne z uwagi na naruszenie I poprawki do Konstytucji; Orzeczenie SN w sprawie Engel v. Vitale, 370 U.S. 421 (1962), dotyczącej obowiązku odmawiania konkretnej modlitwy przed rozpoczęciem lekcji w szkołach, uznające za niekonstytucyjne nakładanie na uczniów w szkołach publicznych takiego obowiązku przez urzędników państwowych. Podobnie SN orzekł w sprawie Wallace v. Jaffree, 472 U.S. 38 (1985).

31 Orzeczenie SN w sprawie Roe v. Wade, 410 U.S. 113 (1973), dotyczącej dopuszczalności dokonania aborcji „na życzenie” do 12. tygodnia ciąży wywiedziona została przez SN z prawa do prywatności (nietykalność osobista i nietykalność mieszkania - IV poprawka do Konstytucji). Utrzymana w orzeczeniu w sprawie Planned Parenthood of Southeastern Pa.v. Casey, 505 U.S. 833 (1992).

32 W orzeczeniu SN w sprawie United States v. Lopez, 514 U.S. 549 (1995), dotyczącej wprowadzenie ograniczenia posiadania broni w pobliżu szkół na podstawie ustawy Kongresu, uznano za niekonstytucyjne. SN orzekł podobnie w sprawie United States v. Morrison, 529 U.S. 598 (2000).

33 W orzeczeniach SN w sprawach Citizens United v. Federal Election Comm'n, 558 U.S. 310 (2010) oraz McCutcheon v. Fed. Election Comm'n, 572 U.S. (2014), w których konserwatyści domagają się nieograniczonego prawa do finansowania kampanii wyborczych, uznano ograniczenia w tym zakresie za niekonstytucyjne (sprzeczne z I poprawką do konstytucji gwarantującą freedom of speech).

34 Oraz wszystkich innych funkcjonariuszy Stanów Zjednoczonych na urzędy utworzone ustawą, chyba że Konstytucja przewiduje inny tryb obsadzania ich.

35 Zwykle kandydatów Prezydent wyznacza spośród sędziów niższych sądów, którzy ukończyli najlepsze uczelnie amerykańskie (np. należące do Ivy League). Dostęp do zawodu 
przez sędziów ${ }^{36}$, w połączeniu z doktryną substantive due process, która „dała Sądowi władzę de facto stanowienia prawa" ${ }^{37}$, przypisywaną mu rolą najwyższego interpretatora konstytucji oraz brak związania własnymi orzeczeniami, mogą w praktyce znacząco wpływać na zasadę stare decisis wzmacniając ją lub ograniczając. W przypadku orzeczenia SN dotyczącego stosowania kary śmierci w sprawie Gregg vs. Georgia (1976) ${ }^{38}$ pozostającego w sprzeczności z wcześniejszym orzeczeniem SN w sprawie Furman vs. Georgia (1972) ${ }^{39}$ doktryna ta pozostaje praktycznie pominięta.

Co więcej, w związku ze sposobem obsadzania stanowisk sędziowskich pojawia się krytyka legitymizacji samej władzy sądowniczej, a w szczególności sędziów SN orzekających o zgodności ustaw z konstytucją, polegająca na kwestionowaniu uprawnień osób (sędziów), które nie będąc wybieranymi na swoje stanowiska, mogą unieważniać przepisy ustaw uchwalane przez suwerena, a z uwagi na największą siłę oddziaływania orzeczeń SN, mogą nawet stanowić bodziec dla Kongresu do zmian samej konstytucji poprzez uchwalenie poprawek ${ }^{40}$. W odpowiedzi najczęściej słychać głosy, że właśnie w pro-

jest łatwiejszy niż w Wielskiej Brytanii, ponieważ od kandydatów na sędziów nie wymaga się długiego stażu pracy. Wystarczy zdać egzamin prawniczy i ubiegać się o nominację sędziowską.

36 „Dopóki sprawują go nienagannie” (art. III \$1 Konstytucji), co oznacza, że sędziowie mogą sprawować swojej funkcje, o ile nie zostanie zastosowana wobec nich skutecznie procedura impeachmentu (usunięcia ze stanowiska), sędzia nie przejdzie na emeryturę lub sam nie zrezygnuje.

37 „Poszerzyła też znacząco rozumienie pojęcia due proces (...)”.W decyzji SN [Slaughter-House Cases, 83 U.S. 36 (1873)] „pojawiła się (choćjedynie w zdaniu odrębnym) mglista i dająca olbrzymie możliwości doktryna mandatu ogólnego (tzw. materialnego procesu sądowego substantive due proces), która została następnie użyta otwarcie w Lochner v. New York (1905), dając mu [SN - przypis autora], władzę de facto stanowienia prawa”, A. Bryk, Orzecznictwo Sądu Najwyższego Stanów Zjednoczonych jako autonomiczne źródto tworzenia norm konstytucyjnych, „Studia Iuridica Lublinensia” 2016, vol. XXV, nr 3, s. 119-120.

38 W konsekwencji orzeczenia SN wydanego sprawie Greggv. Georgia, 428 U.S. 153 (1976) przywrócono karę śmierci, której stosowanie pozostawiono w gestii poszczególnych stanów.

39 Orzeczenie SN w sprawie Furman v. Georgia, 408 U.S. 238 (1972) doprowadziło de facto do wprowadzenia moratorium na stosowanie kary śmierci w USA.

40 Zob. P. Mikuli, op.cit., s. 103. Skutki orzeczenia w sprawie Dred Scott vs. Stanford, 60 U.S. 393 (1857) zostały unieważnione poprzez uchwalone przez Kongres XIII (1865) i XIV (1868) poprawki do Konstytucji. Oprócz tych, jeszcze tylko dwie inne poprawki uchwalone przez Kongres obaliły precedensy SN, tj. XVI i XXVI. 
cesie wyborów sędziowie narażeni byliby na utratę bezstronności i upolitycznienie (jak w przypadku wyborów powszechnych sędziów sądów stanowych).

Zmiana składu sędziowskiego z wyraźnym „przetasowaniem sił” w stosunku do poprzedniego składu z uwagi na poglądy lub wyznanie sędziów jak również zmiana sytuacji społeczno-politycznej (w tym zmiana prezydenta), czy też oczekiwania społeczne wobec SN, mogą wpływać na radykalną zmianę wcześniejszych orzeczeń, prowadząc nawet do instrumentalnego potraktowania doktryny stare decisis poprzez jej pomijanie przy wydawaniu kolejnych orzeczeń w podobnych sprawach ${ }^{41}$.

Z jednej strony, $\mathrm{z}$ uwagi na rozproszony charakter sądowej kontroli konstytucyjności prawa w USA, doktryna stare decisis ma bardzo istotne znaczenie dla uwspólniania orzecznictwa sądów, przyczyniając się co najmniej do łagodzenia poczucia niepewności prawnej obywateli. Szczególną rangę w tym kontekście zyskują orzeczenia Federalnego Sądu Najwyższego USA z uwagi na moc ich oddziaływania na orzeczenia sądów niższej instancji, a nawet na tworzenie prawa stanowionego. Z drugiej zaś strony szczególny charakter tej doktryny doznaje ograniczeń na poziomie sądów niższej instancji poprzez teoretyczne i faktyczne zawężenie skuteczności wydawanych wyroków jedynie do stron procesu (inter partes), a na poziomie samego SN poprzez brak związania własnymi wyrokami, a w konsekwencji poprzez możliwość ich unieważniania w procedurze overruling, rozszczelniającej system spójności wydawanych orzeczeń. Mając jednak na uwadze prawotwórczy charakter rozstrzygnięć sądów (które konkretyzują ${ }^{42}$, a czasem nawet zmieniają znaczenie poszczególnych norm konstytucyjnych (SN)), dokonywanych, jak podnoszą krytycy judicial review, przez nominowane i zatwierdzane przez polityków, a nie naród, zasadniczo nieusuwalne składy sędziowskie, niepozbawione własnych przekonań ideologicznych, w przeciwieństwie do legitymacji dokonywania kontroli konstytucyjności prawa, wynikającego wprost

${ }^{41}$ Zob. S.J. Burton, op.cit., s. 1710. Autor podnosi, iż SN nie związany własnymi precedensami z biegiem czasu może się wahać wraz ze zmieniającym się składem Sądu, przyczyniając się do niemożliwego do zaakceptowania braku ciągłości i niestabilności, wpływając negatywnie na legitymację Sądu.

$42,(. .$.$) w systemie amerykańskim to sąd przyjmuje rolę organu, który konkretyzuje$ przepisy konstytucji”, S. Kubas, Judicial review - geneza i rozwój, [w:] Konstytucja i sądowe gwarancje jej ochrony. Księga jubileuszowa Profesora Pawła Sarneckiego, red. K. Świerk-Bożek, Kraków 2004, s. 142. 
z Konstytucji, muszą być weryfikowane z czasem w celu uwzględnienia aktualnej sytuacji politycznej, gospodarczej i społecznej, umożliwiając SN wycofanie się z niesprawiedliwych, czasem wręcz wstydliwych precedensów wychodząc naprzeciw oczekiwaniom społeczeństwa. Jednakże weryfikacja własnych orzeczeń przez uzupełniane składy sędziowskie nominatami jednej lub drugiej partii, wpływających na „rozłożenie sił” i głosów w SN, może przyczyniać się również do upolitycznienia tegoż oraz jego ostatecznych przecież wyroków wbrew oczekiwaniom obywateli, a konsekwencji do obniżenia zaufania społecznego do wymiaru sprawiedliwości. Ci zaś zdają się być świadomi bezpośredniego wpływu precedensów SN na ich życie, dotyczących w szczególności praw i wolności obywatelskich zakorzenionych w samej Konstytucji. Obawom względem ich ograniczenia dali wyraz Amerykanie demonstrując w październiku br. przed budynkiem SN przeciw zaprzysiężeniu Bretta Kavanaugha - drugiego już konserwatywnego sędziego nominowanego przez Prezydenta Donalda Trumpa - przyczyniającego się do przewagi liczebnej sędziów o poglądach konserwatywnych, wywodzących się z obozu republikańskiego (5:4).

Doktryna stare decisis choć pełni ważną rolę w ramach judicial review ${ }^{43}$, choć doznaje licznych, istotnych ograniczeń, nie tracąc jednak przy tym na doniosłości w odniesieniu do orzeczeń w sprawach cywilnych i karnych.

\section{Literatura}

Brewer-Carías A.R., Judicial review in comparative law, Cambridge 1989.

Bryk A., Orzecznictwo Sądu Najwyższego Stanów Zjednoczonych jako autonomiczne źródło tworzenia norm konstytucyjnych, „Studia Iuridica Lublinensia” 2016, vol. XXV, nr 3. Burton S.J., The conflict between stare decisis and overruling in constitutional adjudication, "Cardozo Law Review" 2014, t. 35.

Collins C.W., The Fourteenth Amendment and the States, Boston 1974.

Constitutional Stare Decisis, "Harvard Law Review" 1990, t. 103, nr 6.

Fallon, Jr.R.H., Stare Decisis and the Constitution: An Essay on Constitutional Methodology, “New York University Law Review” 2001, t. 76, nr 2.

43 Zasada stare decisis zapewnia, że zmiany w prawie konstytucyjnym zainicjowane przez sędziów zaistnieją, gdy sąd z namysłem rozważy ich konsekwencje, w pełni uznając instytucjonalną rolę sądów - zob. Constitutional Stare Decisis..., s. 1344. 
Farber D.A., The Rule of Law and the Law od Precedents, "Minnesota Law Review" 2000, t. 90 .

Garlicki L., Sąd Najwyższy Stanów Zjednoczonych Ameryk: konstytucja - polityka - prawa obywatelskie, Wrocław 1982.

Kozel R.J., Stare Decisis as Judicial Doctrine, "Washington and Lee Law Review" 2010, t. 67.

Kubas S., Judicial review - geneza i rozwój, [w:] Konstytucja i sądowe gwarancje jej ochrony. Księga jubileuszowa Profesora Pawła Sarneckiego, red. K. Świerk-Bożek, Kraków 2004. Ludwikowska A.M., Ludwikowski R.R., Sądy w Stanach Zjednoczonych. Struktura i Jurysdykcja, Toruń 2008.

Maltese J.A., The selling of Supreme Court nominees, Baltimore; London 1995.

Mikuli P., Zdekoncentrowana sądowa kontrola konstytucyjności prawa. Stany Zjednoczone i państwa europejskie, Kraków 2007. 